\title{
Static and kinetic friction coefficients of Scots pine (Pinus sylvestris L.), parallel and perpendicular to grain direction
}

\author{
J.R. Aira ${ }^{\mathrm{a}} \bowtie$, F. Arriaga ${ }^{\mathrm{a}}$, G. Íñiguez-González ${ }^{\mathrm{a}}, \mathrm{J}_{\text {. Crespo }}^{\mathrm{b}}$ \\ a. Universidad Politécnica de Madrid. (Madrid, Spain) \\ b. Universidad de Santiago de Compostela (Santiago de Compostela, Spain) \\ $\triangle$ joseramonaira@gmail.com
}

\begin{abstract}
SUMMARY: In this study the static $\left(\mu_{\mathrm{e}}\right)$ and kinetic $\left(\mu_{\mathrm{d}}\right)$ coefficients of friction were obtained for Pinus sylvestis L. sawn timber of Spanish origin. Friction between transverse surfaces sliding perpendicular to the grain (tangential direction) and radial surfaces sliding parallel to the grain was analyzed. A specifically designed device was used for tests, which makes it possible to apply contact pressure and measure displacements and applied loads simultaneously. Coefficients of friction between transverse surfaces $\left(\mu_{\mathrm{e}}=0,24 ; \mu_{\mathrm{d}}=0,17\right)$ were about twice of the coefficients of friction between radial surfaces $\left(\mu_{\mathrm{e}}=0,12 ; \mu_{\mathrm{d}}=0,08\right)$. Furthermore, these values are located within normal values of those commonly reported for softwood. The results are considered preliminary due to the small number of specimens.
\end{abstract}

KEYWORDS: Friction; Wood; Physical properties

Citation I Citar como: Aira, J.R.; Arriaga, F.; Íñiguez-González, G.; Crespo, J. (2014). Static and kinetic friction coefficients of Scots pine (Pinus sylvestris L.), parallel and perpendicular to grain direction. Mater. Construcc. 64 [315], e030 http://dx.doi.org/10.3989/mc.2014.03913.

RESUMEN: Coeficientes de rozamiento estático y dinámico en la madera de pino silvestre (Pinus sylvestris L.), según las direcciones paralela y perpendicular a la fibra. En este estudio se determinaron los coeficientes de rozamiento, estático $\left(\mu_{\mathrm{e}}\right)$ y dinámico $\left(\mu_{\mathrm{d}}\right)$, en madera aserrada de Pinus sylvestris L. de procedencia española, diferenciando si se produce el contacto entre secciones de corte transversal con deslizamiento en dirección perpendicular a la fibra (en dirección tangencial), o entre secciones de corte radial con deslizamiento paralelo a la fibra. Para la realización de los ensayos se ha utilizado un dispositivo, diseñado específicamente, que posibilita la aplicación de una presión de contacto y la medición del desplazamiento y de la fuerza aplicada de manera simultánea, permitiendo la obtención de los coeficientes de rozamiento estático y dinámico. Los coeficientes de rozamiento obtenidos entre secciones transversales $\left(\mu_{\mathrm{e}}=0.24 ; \mu_{\mathrm{d}}=0.17\right)$ fueron del orden del doble de los coeficientes de rozamiento entre secciones radiales $\left(\mu_{\mathrm{e}}=0.12 ; \mu_{\mathrm{d}}=0.08\right)$. Además, estos valores se encuentran dentro de los valores que aparecen habitualmente en la bibliografía para madera de coníferas. Debido al escaso tamaño de la muestra los resultados se consideran preliminares.

PALABRAS CLAVE: Rozamiento; Madera; Propiedades físicas

Copyright: (C) 2014 CSIC. This is an open-access article distributed under the terms of the Creative Commons Attribution-Non Commercial (by-nc) Spain 3.0 License.

\section{INTRODUCTION}

In traditional or carpentry joints, forces are transmitted from one piece to the other through contact surfaces. These forces lead to normal and tangential stresses between surfaces, and the friction forces that oppose sliding between the elements forming the joint. Knowledge of friction or friction forces is important to correctly analyze the mechanical behavior of traditional joints of wooden structures, 
and it is commonly used in finite element simulation of timber joints (1-4).

Friction is a force that opposes the sliding or rolling motion of bodies when they are in contact at one of their surfaces. The origin of friction forces is due to roughness or surface irregularities present in most bodies, while molecular attraction between the contact surfaces may cause microwelding that must be broken to start sliding, figure 1 .

Surfaces have more protuberances when they are rougher. These protuberances keep elements in contact and determine the actual area in contact. When the pressure between contact surfaces increases, the actual area in contact increases as protuberances are deformed when they are crushed.

A body with a weight $\mathrm{P}$ which is resting on a horizontal surface is considered, Figure 2. By applying a force $\mathrm{F}$ parallel to the surface that does not change the rest position of the body, forces $F$ and $P$ give the resultant force $F_{1}$. The equilibrium of forces occurs when force $F_{1}$ is balanced by force $F_{2}$. If force $F_{2}$ is decomposed into its vertical and horizontal components, two forces are obtained: $\mathrm{N}$, which is the reaction or force that a horizontal plane exerts on the body due to its own weight, and R which is the force that opposes the motion of the body or friction force.

Figure 3 shows the friction force $\mathrm{R}$ depending on the applied force F.

As the applied force, $\mathrm{F}$, is increased from point 0 to point $\mathrm{A}$, the static friction force, $\mathrm{R}_{\mathrm{e}}$, is increased in the same module until a time when the body is about to slide. That time corresponds to maximum static friction, and its value is obtained by the expression: $\mathrm{R}_{\mathrm{e} \text { max }}=\mu_{\mathrm{e}} \cdot \mathrm{N}$, where $\mu_{\mathrm{e}}$ is the static friction coefficient. If the applied force, $F$, remains equal to $R_{e \max }$, point $\mathrm{B}$, the body starts moving with an acceleration of: $a=\left(R_{e \text { max }}-R_{d}\right) / m$, where $m$ is the mass of the body. If the applied force, $\mathrm{F}$, is increased, point $\mathrm{D}$, the net force on the body increases as does acceleration of the body. At point $\mathrm{C}$, the applied force, $\mathrm{F}$, is equal to the kinetic friction force, $R_{d}$, so that the net force on the body is zero and it moves with a constant velocity. At point E, the applied force, F, drops to zero so that the force acting on the body is $-R_{d}$, the acceleration is negative and the velocity decreases until the body stops.

Therefore, once the body is in motion for any value of the applied force, $\mathrm{F}$, the kinetic friction force is always: $R_{d}=\mu_{d} \cdot N$. If the applied force, $F$, is equal to $\mathrm{R}_{\mathrm{d}}$, the body moves with constant velocity and no inertial forces oppose the motion. If the force $\mathrm{F}$ is greater than $R_{d}$, the movement will be accelerated, while it will decelerate if it is lower (5).

For any two surfaces in contact, the static friction coefficient is usually higher than the kinetic friction coefficient $\left(\mu_{\mathrm{e}}>\mu_{\mathrm{d}}\right)$.

Friction coefficients for wood depend primarily on moisture content and surface roughness, which is in turn determined by, among other factors, anatomical properties, hardness and machining characteristics. In species without a high content of elements on their surface which favour the sliding, such as oily or waxy exudations, coefficients do not vary much from one species to another (6).

Friction coefficients increase with moisture content, up to the point of fiber saturation. After that moment, values remain constant until there is a substantial amount of free water on the surface, causing reduction again. Moreover, kinetic friction depends on the sliding velocity, so that at moisture contents of less than $20 \%$, the kinetic friction coefficient varies little with the sliding velocity, while at high moisture contents kinetic friction decreases relevantly with increasing velocity (6).

Wood is considered to be an orthotropic material, and each principal plane of wood has a different degree of roughness, so friction coefficients depend on the surfaces which are in contact. In general the friction between two pieces of wood can be studied for each cut surface corresponding to material symmetry planes: transverse surfaces (cut perpendicular to the grain) and two cut surfaces parallel to the grain (radial and tangential). Within each plane, sliding can be studied in two perpendicular directions (radial and tangential for the transverse surfaces, and parallel and perpendicular to the grain for parallel surfaces). It is also possible to combine two different cut surfaces, so the possibilities multiply. For this reason, the study of friction will be particularized for each situation.

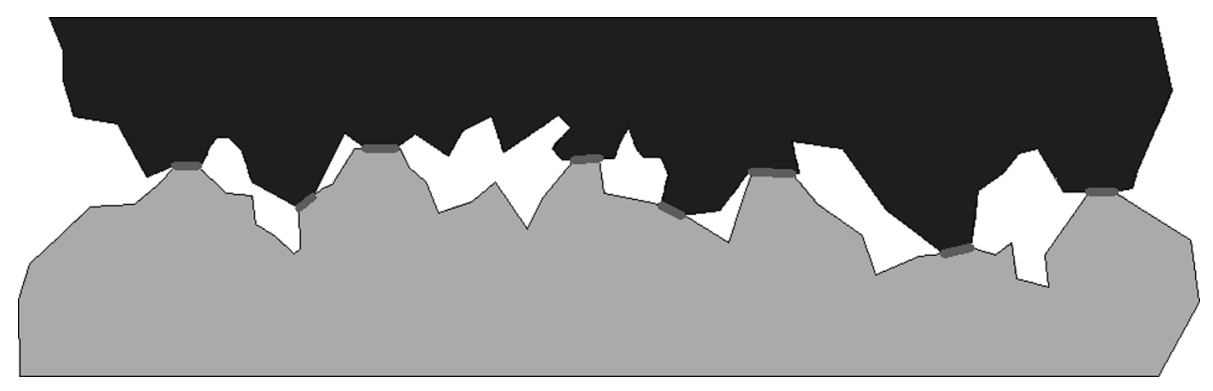

FIGURE 1. Roughness between contact surfaces. 


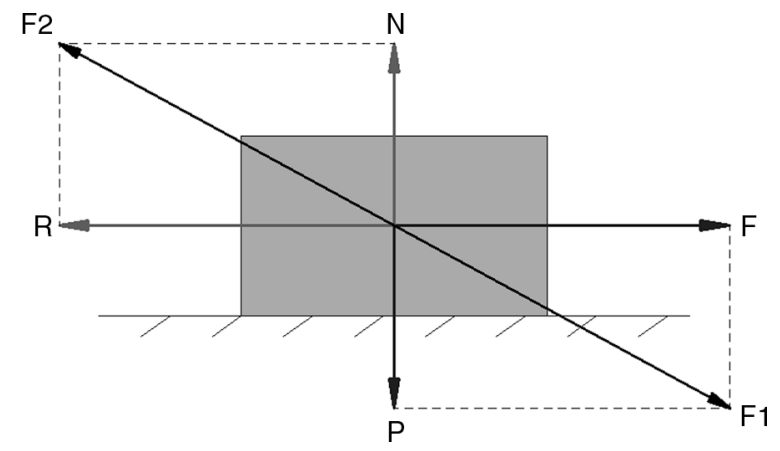

FIGURE 2. Force balance in a resting body.

Moreover, the cuts made along surfaces parallel to the grain (radial and tangential) give rise to a slight orientation of the roughness on the cut plane. This effect is commonly called "with the woodgrain and against the woodgrain", which also influences friction values.

In research works carried out with products derived from wood, Laminated Strand Lumber (LSL) and Laminated Veneer Lumber (LVL), the existence of a relationship between the values of the friction coefficients and contact pressure was determined, so that friction coefficients decrease nonlinearly with increasing contact pressure (7).

The usual kinetic friction coefficient values for wood are said in the scientific literature to vary from 0.3 to 0.5 for dry and smooth wood against hard smooth surfaces, 0.5 to 0.7 for intermediate moisture content and 0.7 to 0.9 for near fiber saturation (6). Other values reported in the literature are shown in table 1.

Design values of static friction coefficients between softwood and between softwood and concrete are indicated in the UNE-EN 1995-2 standard (10), for the design of stress-laminated deck plates, table 2.

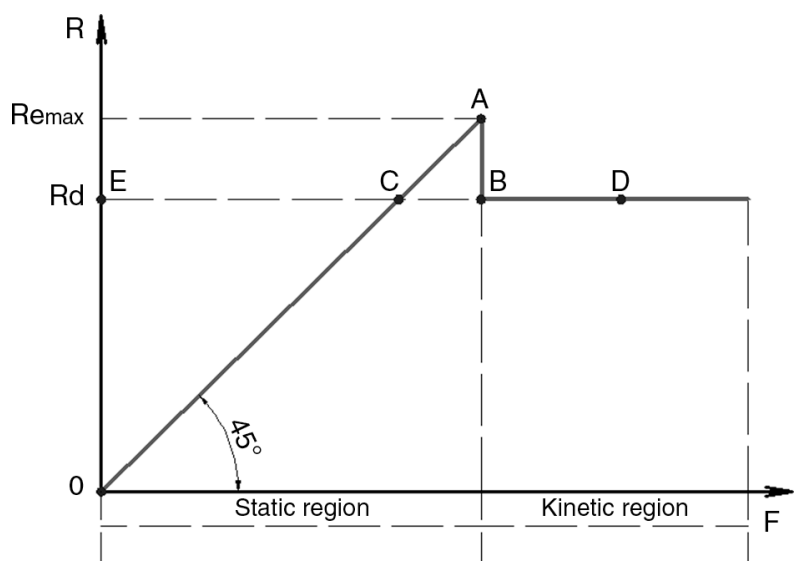

FiguRE 3. Graphical representation of the friction force R according to the applied force $\mathrm{F}$.
TABLE 1. Timber friction coefficients (8 y 9)

\begin{tabular}{lcc}
\hline & \multicolumn{2}{c}{ Friction coefficients } \\
\cline { 2 - 3 } Material & Static $\left(\mu_{\mathrm{e}}\right)$ & Kinetic $\left(\mu_{\mathrm{d}}\right)$ \\
\hline Timber-Timber & $0.25-0.50$ & 0.20 \\
Waxed timber-Wet snow & 0.14 & 0.10 \\
Waxed timber-Dry snow & - & 0.04 \\
Oak-Oak & & \\
parallel to the grain & 0.62 & 0.48 \\
perpendicular to the grain & 0.54 & 0.34 \\
parallel-perpendicular & 0.43 & 0.19 \\
Timber-Stone & 0.38 & $<0.7$ \\
Timber-Concrete & 0.62 & - \\
Timber-Brick & 0.60 & - \\
\hline
\end{tabular}

Currently there is no European standardized test method for determining friction coefficient. The American standard ASTM G115-10 (11) specifies general methodology. In recent years some research has been conducted in Spain, leading to a proposed testing methodology. The friction between transverse surfaces (sliding perpendicular to the grain) in glued laminated timber specimens of Picea abies L. Karst with a moisture content of $12 \%$ was analyzed, obtaining a static coefficient of 0.47 and a kinetic coefficient of 0.31 (12). Glued laminated timber specimens of the same species with a moisture content of $10 \%$ were also tested to obtain the friction between dovetail joint flanks, resulting in a static coefficient of 0.42 and a kinetic coefficient of 0.27 (2).

In this work, as will be explained in the next section, friction coefficients necessary to study halved and tabled timber scarf joints are obtained. The static and kinetic friction coefficients of Scots pine sawn timber (Pinus sylvestris L.) of Spanish origin are determined, differentiating if contact occurs between transverse surfaces sliding perpendicular to the grain (tangential direction), or radial surfaces sliding parallel to the grain.

TABLE 2. Design values for the static friction coefficient $\mu \mathrm{e}(10)$

\begin{tabular}{lllll}
\hline & $\begin{array}{c}\text { Perpendicular } \\
\text { to the grain }\end{array}$ & \multicolumn{3}{c}{$\begin{array}{c}\text { Parallel } \\
\text { to the grain }\end{array}$} \\
\cline { 2 - 5 } Material & \multicolumn{3}{c}{ Moisture content (\%) } \\
\cline { 2 - 5 } & $\mathbf{1 1 2}$ & $\mathbf{2 1 6}$ & $\mathbf{1 1 2}$ & $\mathbf{2 1 6}$ \\
\hline Sawn timber-Sawn timber & 0.30 & 0.45 & 0.23 & 0.35 \\
Planed timber-Planed timber & 0.20 & 0.40 & 0.17 & 0.30 \\
Sawn timber-Planed timber & 0.30 & 0.45 & 0.23 & 0.35 \\
Timber-Concrete & 0.40 & 0.40 & 0.40 & 0.40 \\
\hline
\end{tabular}

Note: For moisture content values between 12 and $16 \%$ can be interpolated linearly. 


\section{MATERIAL AND METHODS}

To determine the friction coefficients a specific device is used. It is was designed and manufactured specifically for this purpose, and it is located in the laboratory of the Platform for Structural Timber Engineering (PEMADE) of the University of Santiago de Compostela (USC), Figure 4.

The test specimens are placed in two plates called specimen-brackets, one upper and one lower. After placing the specimens into the specimen-bracket plates, six weights are coupled together so that surface normal force, $\mathrm{N}$, is known previously. The weights exert a total force of $2435.3 \mathrm{~N}$.

The lower specimen-bracket is mobile and receives an external load through a braided steel $3 \mathrm{~mm}$ diameter cable which is fixed to the piston that exerts the load. The device does not register the load, but only records the vertical displacement of the piston.

The upper specimen-bracket is coupled to a bending beam load cell which restricts its horizontal displacement and records the load applied in the said direction. This load cell has a high nominal sensitivity $(2 \mathrm{mv} / \mathrm{v})$ and a loading capacity of $5441.1 \mathrm{~N}$. The rear of the specimen-bracket contains a threaded $10 \mathrm{~mm}$ diameter rod which is inserted through a hole into the load cell. Finally, a nut located at the end of the rod is tightened to achieve perfect adjustment.
The weights are placed directly on the upper specimen-bracket descending vertically by two steel guides. Contact is made by two Teflon plates, one affixed to the bottom of the weights-bracket and the other affixed to the top of the specimen-bracket.

The upper specimen is positioned at a distance of approximately $1 \mathrm{~cm}$ recessed relative to the lower specimen to eliminate noise caused by friction between the edges of the specimens when starting movement, Figure 5.

The test is performed with constant velocity of piston displacement to prevent the onset of inertial forces during the sliding between specimens. Thus the value of kinetic friction coefficient, $\mu_{\mathrm{d}}$, can be obtained graphically in a simple manner, since the modulus of friction force $R_{d}$ and the modulus of applied load, F, are equal. By observing Figure 3, the testing methodology follows the steps below: 0-A, $\mathrm{A}-\mathrm{B}$ and $\mathrm{B}-\mathrm{C}$. Figure 6 shows schematically the working of the friction device, together with the balance of forces involved.

A computer connected to the piston and the load cell records the displacement values and friction force at all times, while simultaneously calculating the friction coefficients.

The lower specimen-bracket is subjected to the friction between the wood specimens, $\mathrm{R}_{\mathrm{mm}}$, at the top, and friction with the specimen-bracket lubricated steel rails on which slides, $\mathrm{R}_{\mathrm{aa}}$, at the bottom.

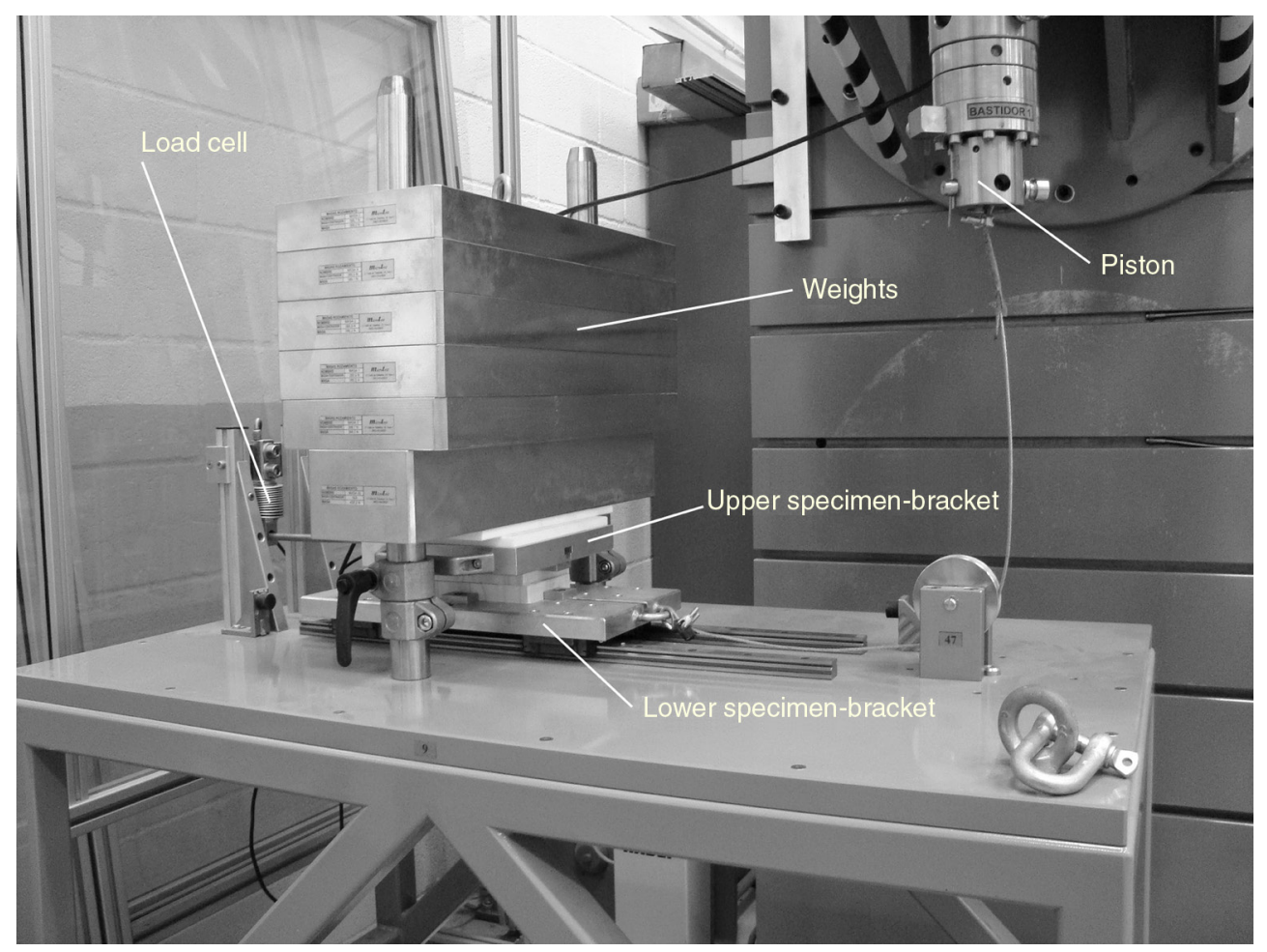

FIgURE 4. Device for friction testing. 


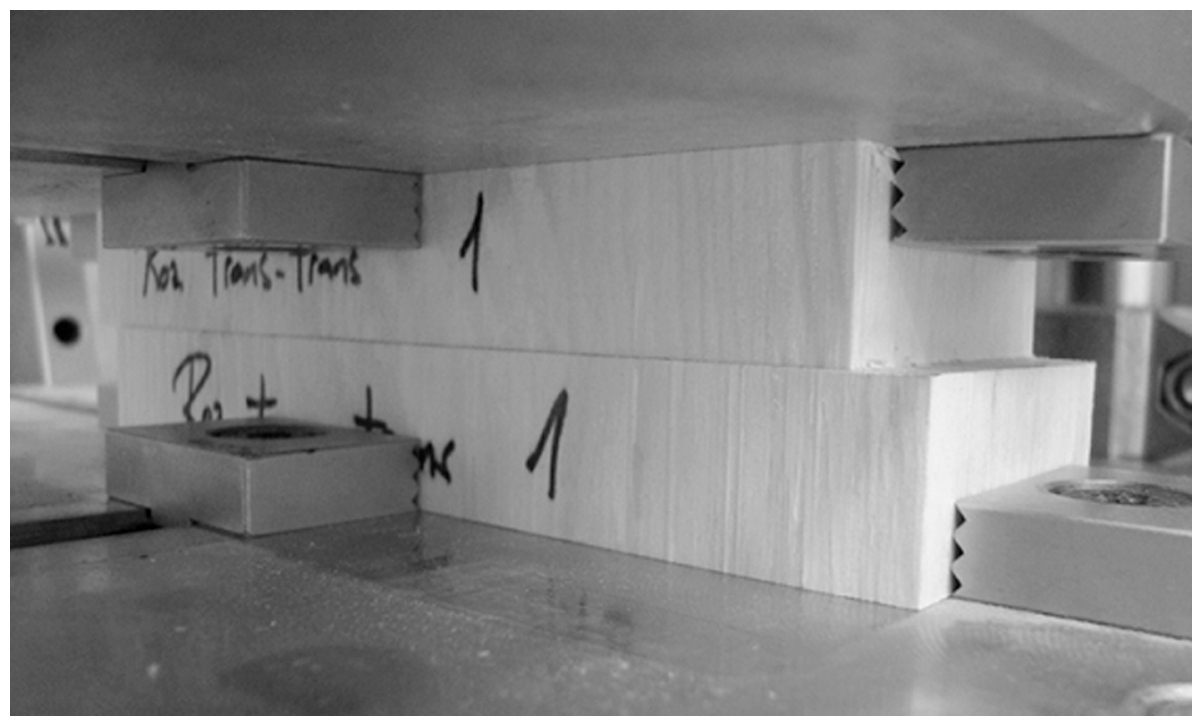

FIGURE 5. Relative position of friction specimens.

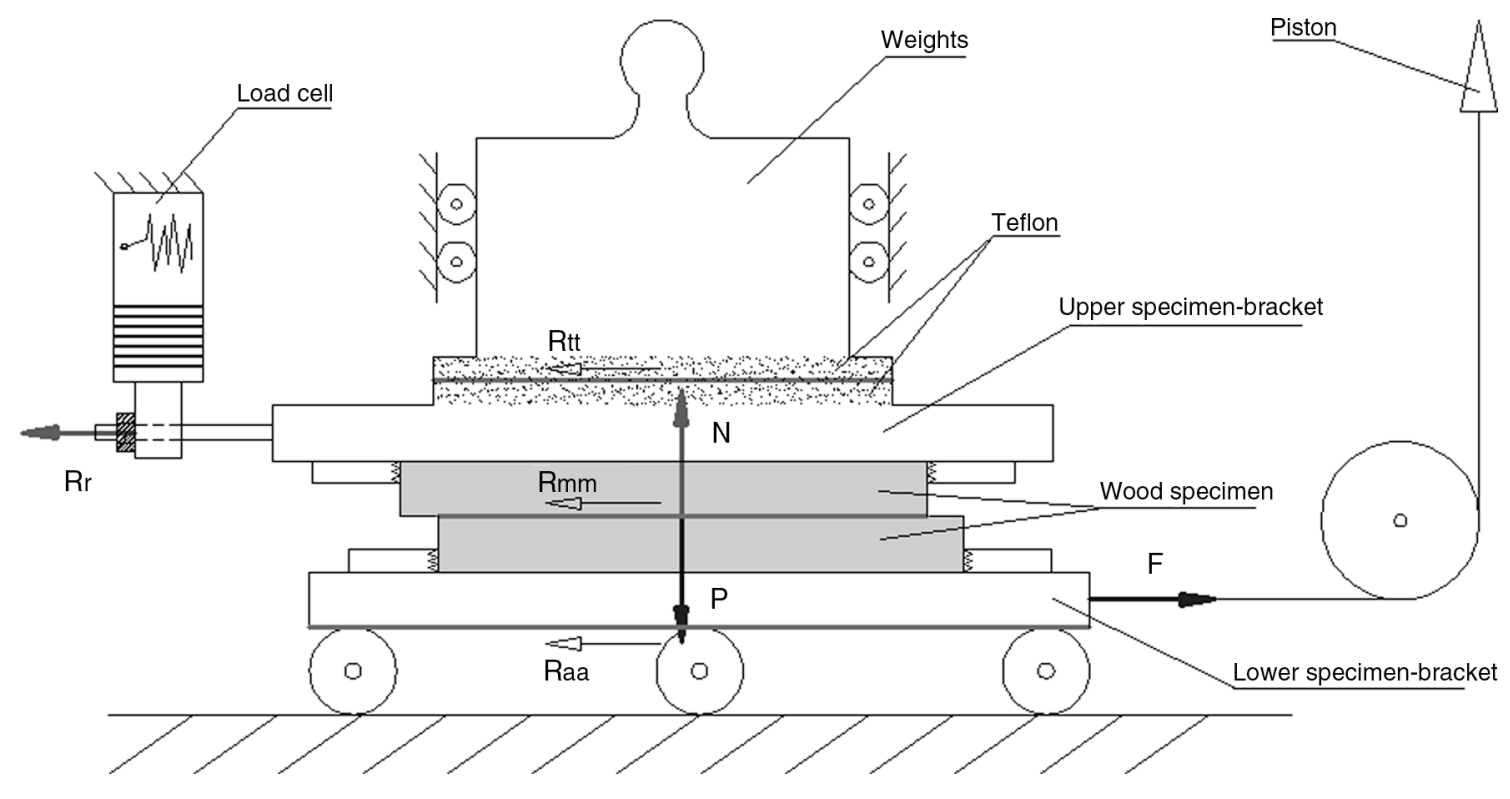

Figure 6. Scheme of the friction test device.

The upper specimen-bracket is subjected to friction between the Teflon plates, $\mathrm{R}_{\mathrm{t}}$, at the top, and the friction between the wood specimens, $R_{\mathrm{mm}}$, at the bottom. The friction coefficents verify the following relationship: $\mathrm{R}_{\mathrm{mm}}>>\mathrm{R}_{\mathrm{aa}}>\mathrm{R}_{\mathrm{tt}}$. Applying the external load, $F$, the upper specimen-bracket remains in equilibrium due to the friction forces that oppose movement $\left(\mathrm{R}_{\mathrm{mm}}\right.$ and $\left.\mathrm{R}_{\mathrm{aa}}\right)$ verifying that: $F=R_{m m}+R_{a a}$. In turn, load $F$ is transmitted to the upper specimen-bracket through the friction between the wood specimens $\left(\mathrm{R}_{\mathrm{mm}}\right)$. The transmitted load is recorded by the load cell, $R_{r}$, verifying the following balance: $F=R_{r}+R_{t t}$. By equalizing the two equations, the friction between the wood specimens is obtained: $R_{m m}=R_{r}+R_{t t}-R_{a a}$, where $R_{r}$ is the recording load cell and $R_{t t}-R_{a a}$ has an experimental value of $-0.08671 \cdot \mathrm{N}$. The software is calibrated so that friction between other elements of the device will not affect the results, i.e. the friction force between wood specimens is directly calculated by the equation: $R_{m m}=R_{r}-0.08671 \cdot N$. This calibration is the same for all test series.

The test is performed at a constant speed of $8 \mathrm{~mm} / \mathrm{min}$ and is interrupted when the kinetic friction coefficient remains constant during piston displacement of $30 \mathrm{~mm}$. 
This research work is part of a larger project studying a type of traditional timber joint called the halved and tabled scarf joint. Figure 7 shows the contact surfaces of this carpentry joint. For this reason, friction coefficients between transverse surfaces sliding perpendicular to the grain (tangential direction) and between radial surfaces sliding parallel to the grain are obtained.

The friction specimens must have the same roughness between contact surfaces as the joint which is being analyzed. Therefore, wood specimens were obtained using the same band saw to cut the joint.

The test material consists of Pinus sylvestris L. wood from the "Valsaín sawmill" (Segovia). 5 test specimens were cut and consecutively numbered to obtain the friction coefficients between transverse surfaces, and 5 other specimens to obtain the friction coefficients between radial surfaces. Each specimen is composed of two parts, upper and lower. The specimens' dimensions are the following:

- Contact between transverse surfaces: 2 pieces of $48 \times 148 \times 20 \mathrm{~mm}$.

- Contact between radial surfaces: 2 pieces of $48 \times 150 \times 20 \mathrm{~mm}$.

The friction specimens are obtained from other larger samples designed for the study of halved and tabled traditional timber scarf joints. These specimens are conditioned according to the guidelines of the UNE-EN 408 standard (13), i.e. in a camera with a controlled atmosphere at a temperature of $(20 \pm 2){ }^{\circ} \mathrm{C}$ and air relative humidity of $(65 \pm 5) \%$. Under these conditions, the equilibrium moisture content of most softwood species is approximately $12 \%$.

Once specimens are conditioned, the moisture content and density are determined according to the guidelines of the UNE-EN 408 standard, by cutting a sample according to the UNE-EN 13183-1 standard (14). The sample is measured and weighed to obtain its mass before drying $\left(\mathrm{m}_{1}\right)$, after which the sample is dried in an oven at a temperature of $(103 \pm 2)^{\circ} \mathrm{C}$ until the mass difference between two successive weighings at an interval of 2 hours is less than $0.1 \%$, and finally the sample is weighed again to obtain the anhydrous mass $\left(\mathrm{m}_{0}\right)$. The sample moisture content expressed as a percentage of the mass is given by the equation: $\mathrm{w}=\left(\left(\mathrm{m}_{1}-\mathrm{m}_{0}\right) / \mathrm{m}_{0}\right) \cdot 100$.

\section{RESULTS AND DISCUSSION}

\subsection{Friction between transverse surfaces (perpendicular to the grain plane and in the tangential sliding direction)}

To assess the variation of the friction coefficient during the test, a graph is made showing the friction coefficient on the ordinate axis and the piston displacement in $\mathrm{mm}$ on the abscissa axis, Figure 8.

Two regions are clearly distinguished in Figure 8:

\section{- Static region}

During the initial phase, the applied load increases linearly to maintain a constant speed of piston displacement. At this stage, the static friction force, $R_{e}$, is at all times equal to the applied external load, F.

As was pointed out above, the maximum value of $\mathrm{R}_{\mathrm{e}}$ corresponds to the upper peak of Figure 8 . At this point, the static friction coefficient is determined by the equation: $\mu_{\mathrm{e}}=\mathrm{R}_{\mathrm{e}} / \mathrm{N}$, and it is obtained directly since $\mathrm{R}_{\mathrm{e}}$ and $\mathrm{N}$ are known.

Figure 8 also shows that the maximum value of $\mathrm{R}_{\mathrm{e}}$ occurs approximately when the piston has moved from 2.5 to $5 \mathrm{~mm}$, depending on the test specimen. This displacement is due to deformation of the steel cable, and also, although theoretically contact surfaces should not slip against each other, to slight sliding in the static region due to the breakage process of microwelding between surfaces, and perhaps due to some shear deformation in both parts of the specimen.
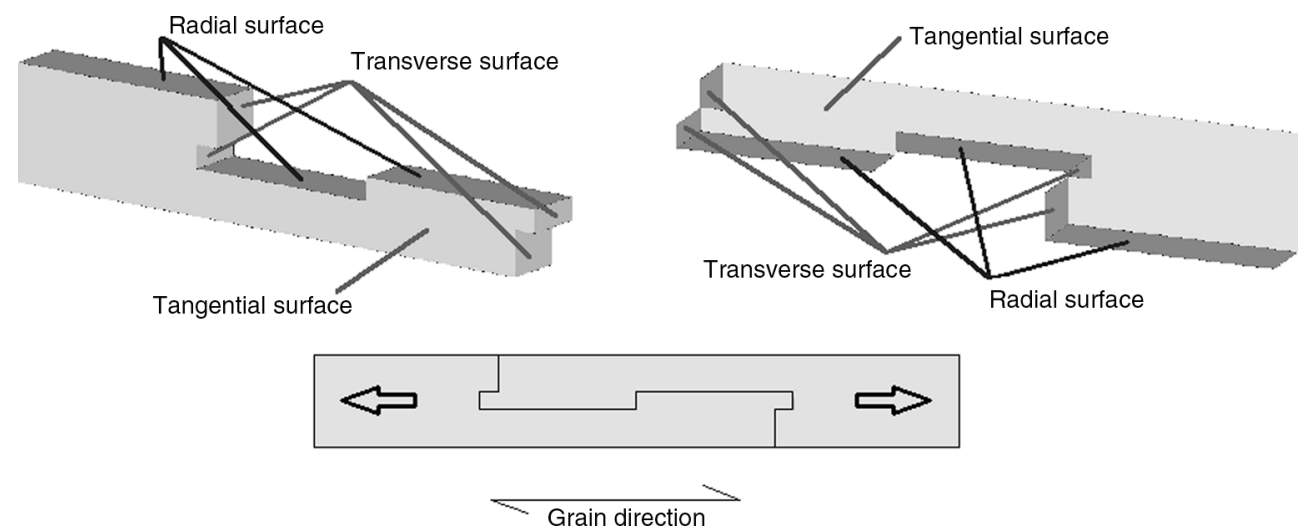

FIgURE 7. Contact surfaces at the halved and tabled traditional timber scarf joint. 


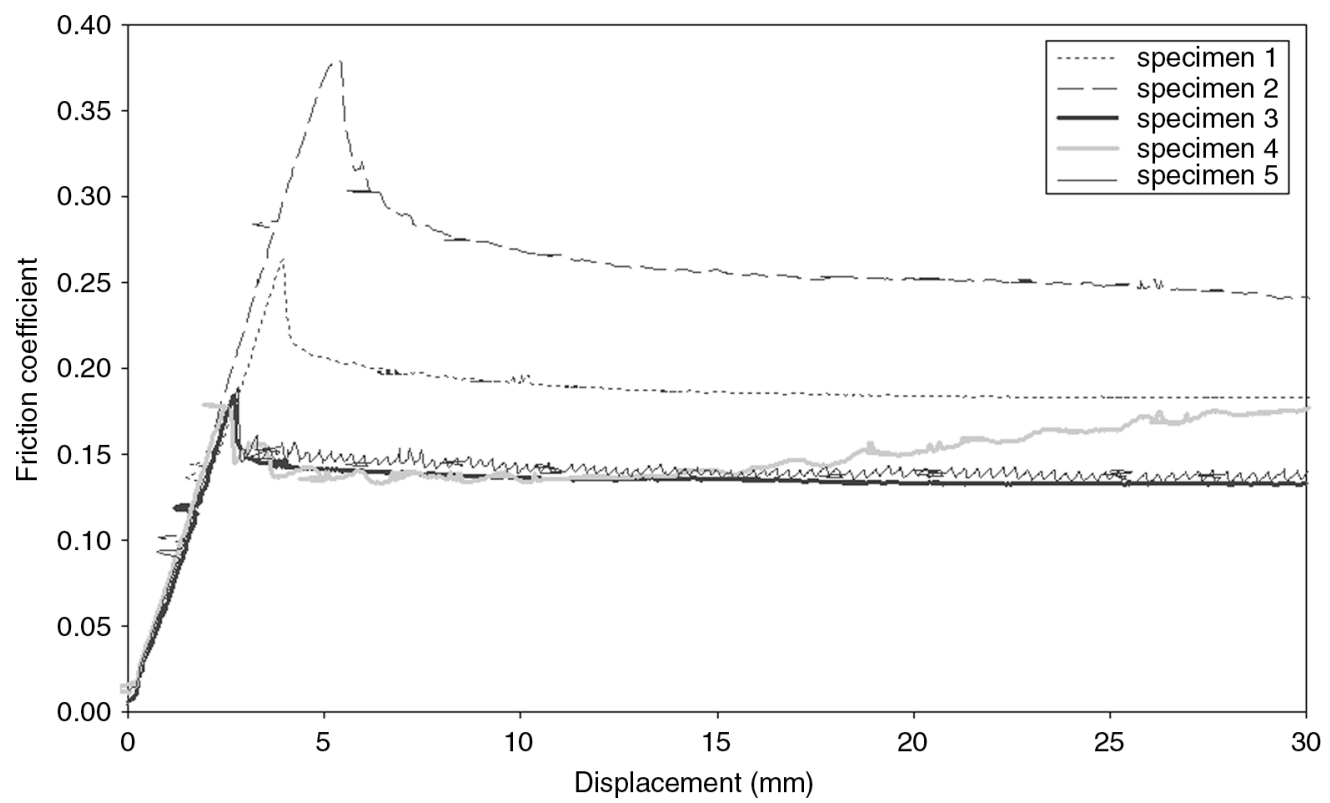

FIGURE 8. Graph of friction coefficients between transverse surfaces.

\section{- $\underline{\text { Kinetic region }}$}

From the upper peak, the friction coefficient declines sharply to stabilize and becomes nearly horizontal.

The friction coefficient is considered to be stable with piston displacement of $15 \mathrm{~mm}$, so that the kinetic friction coefficient $\mu_{\mathrm{d}}$ is determined as the average value in the range $15-30 \mathrm{~mm}$.

The friction coefficients obtained are shown in table 3 .

The friction coefficients between transverse surfaces sliding perpendicular to the grain are at the lower limits of those reported in the scientific literature consulted for general wood. Scots pine wood and most softwoods have a high resin content that favors sliding between surfaces. However, the values reported in the literature do not usually differentiate between softwood or hardwood, between specific surfaces which are in contact or the direction of sliding. When the value of the static friction coefficient obtained (0.24) is compared with the value given in table 2 for softwood sliding perpendicular to the grain $(0.20)$, it is within usual values. The coefficient of variation, although slightly higher, is within normal values for wood.

\subsection{Friction between radial surfaces (sliding direction parallel to the grain)}

To assess friction coefficient variation during the test, a graph was made in the way described for the test between transverse surfaces, Figure 9 .

As was the case in the previous test, the static and kinetic regions can be clearly distinguished, Figure 9. It should be noted that the values of specimen 3 are not considered in subsequent calculations due to the fact that its initial behaviour differs from that of the other specimens, making it impossible to differentiate between the static and kinetic friction coefficients. However, this specimen did not show any differentiating anatomical feature.

TABLE 3. Friction coefficients between transverse surfaces

\begin{tabular}{lcccc}
\hline Specimen & Density $\left(\mathbf{k g} / \mathbf{m}^{\mathbf{3}}\right)$ & Moisture content $\mathbf{( \% )}$ & $\boldsymbol{\mu}_{\mathrm{e}}$ & $\boldsymbol{\mu}_{\mathrm{d}}$ \\
\hline 1 & 482 & 11.84 & 0.26 & 0.18 \\
2 & 464 & 11.90 & 0.38 & 0.25 \\
3 & 466 & 11.98 & 0.18 & 0.13 \\
4 & 540 & 11.67 & 0.18 & 0.16 \\
5 & 483 & 11.51 & 0.19 & 0.14 \\
Averages & $\mathbf{4 8 7}$ & $\mathbf{1 1 . 7 8}$ & $\mathbf{0 . 2 4}$ & $\mathbf{0 . 1 7}$ \\
CV & $6.35 \%$ & $1.61 \%$ & $36.19 \%$ & $27.70 \%$ \\
\hline
\end{tabular}


Moreover, specimens 4 and 5 show a behaviour in sawtooth shape and the friction values are slightly higher than they are for the other specimens. This is due to excess surface resin which still maintains its adhesive properties.

Figure 9 also shows that the maximum value of $\mathrm{R}_{\mathrm{e}}$ occurs when the piston has moved from approximately 1 to $2.5 \mathrm{~mm}$, a shorter displacement than in the previous test.

The friction coefficients obtained are shown in table 4.

The value of the static friction coefficient obtained (0.12) is lower than the value given in table 2 for softwood sliding parallel to the grain $(0.17)$. The difference lies within the expected variability for different species of softwood, and it is also a consequence of the different test methods used, supporting the need to standardize this test methodology.
The coefficient of variation is slightly higher than in the previous test. This may be due to the fact that the fibers are cut longitudinally in radial surfaces, resulting in a less homogeneous surface in terms of roughness than is the case in transverse surfaces where the fibers are cut transversally. In this respect the influence of "woodgrain" should be noted. All tests were carried out "against the woodgrain", since in the initial test no friction was recorded when the tests were made "with the woodgrain". Additionally, the difference between the angles of the "woodgrain" for each of the parts in contact leads to a greater spread of the results.

On the other hand, friction coefficients between transverse surfaces are approximately twice those between radial surfaces. However, it should be noted that number of specimens is small in both tests, and it would be desirable to use a larger sample size in future works.

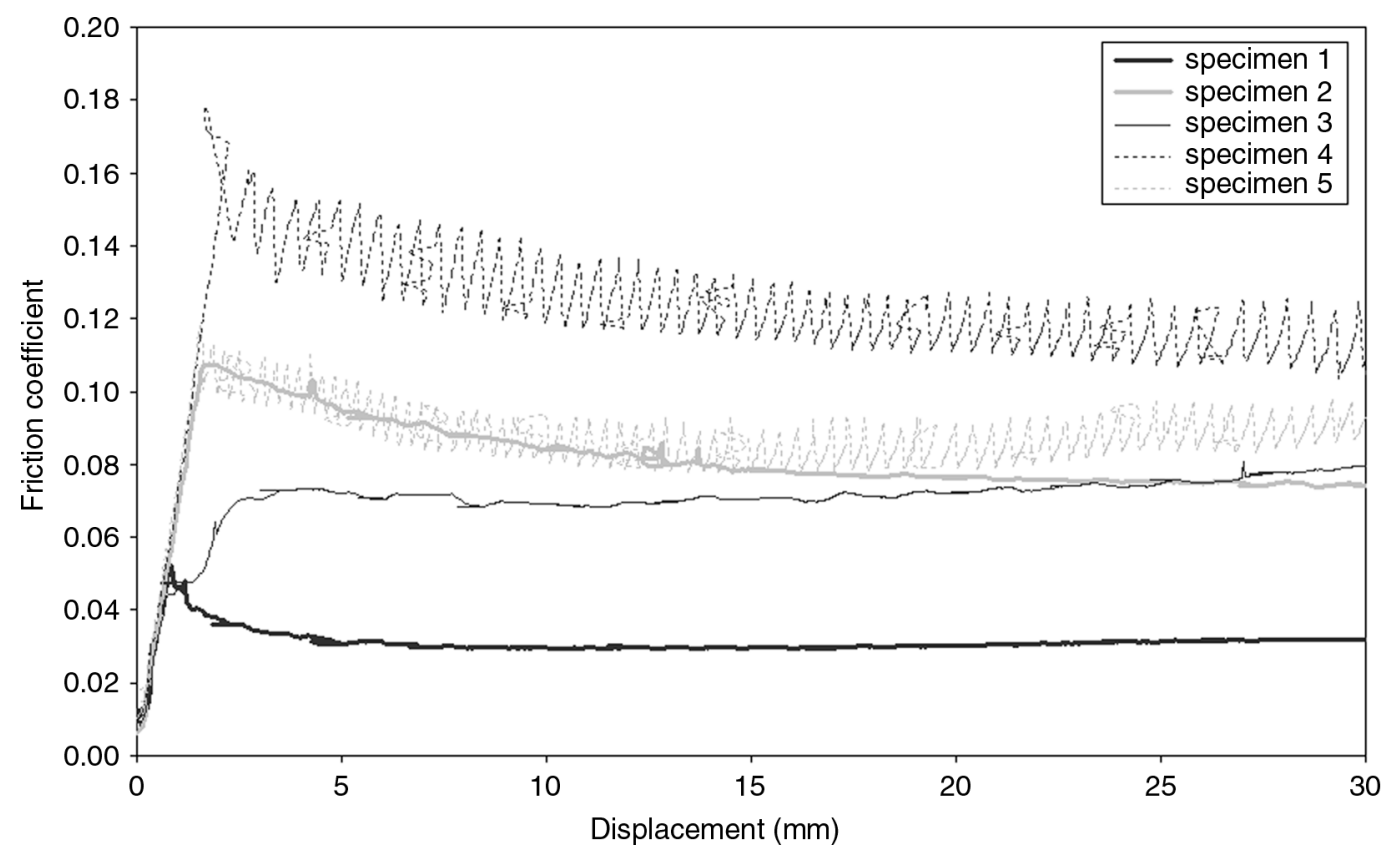

FIGURE 9. Graph of friction coefficients between radial surfaces.

TABLE 4. Friction coefficients between radial surfaces

\begin{tabular}{lcccc}
\hline Specimen & Density $\left(\mathbf{k g} / \mathbf{m}^{3}\right)$ & Moisture content $\mathbf{( \% )}$ & $\boldsymbol{\mu}_{\mathrm{e}}$ & $\boldsymbol{\mu}_{\mathrm{d}}$ \\
\hline 1 & 486 & 11.64 & 0.05 & 0.03 \\
2 & 452 & 11.87 & 0.11 & 0.08 \\
3 & 465 & 12.25 & - & - \\
4 & 550 & 11.51 & 0.18 & 0.12 \\
5 & 477 & 11.37 & 0.12 & 0.09 \\
Averages & $\mathbf{4 8 6}$ & $\mathbf{1 1 . 7 3}$ & $\mathbf{0 . 1 2}$ & $\mathbf{0 . 0 8}$ \\
CV & $7.82 \%$ & $2.94 \%$ & $46.29 \%$ & $46.77 \%$ \\
\hline
\end{tabular}




\section{CONCLUSIONS}

The test device designed to determine friction coefficient provides an easy way to obtain static and kinetic friction coefficients. This method is considered to be appropriate as a possible standard methodology.

Due to the small sample size these results are preliminary. They may not be considered final until tests are conducted with a larger number of specimens.

The friction coefficients between transverse surfaces sliding perpendicular to the grain are about twice the friction coefficients between radial surfaces sliding parallel to the grain. The values obtained are among the usual values reported in the scientific literature for softwood.

The effect known as "woodgrain" significantly affects the friction between surfaces cut parallel to grain direction, so that when the sliding direction between contact surfaces is "with the woodgrain" the friction is negligible.

\section{REFERENCES}

1. Villar, J.R.; Guaita, M.; Vidal, P.; Arriaga, F. (2007) Analysis of the stress state at the cogging joint in timber structures, Biosystems Engineering, n ${ }^{\circ} 96$ (1), pp. 79-90, http://dx.doi.org/10.1016/j.biosystemseng.2006.09.009.

2. Soilán, S.; Arriaga, F.; Baño, V.; Crespo, J.; Guaita, M. (2011a) Análisis del comportamiento de la unión en cola de milano mediante simulación numérica por el método de los elementos finitos, CIMAD $11,1^{\circ}$ Congreso Ibero-Latino Americano de la madera en la construcción, Coimbra, Portugal.
3. Soilán, S.; Arriaga, F.; Guaita, M. (2011b) Análisis tensional mediante simulación numérica de la unión en cola de milano redondeada entre vigas y viguetas de madera, VI Congreso Ibérico de Agro-Engenharia, Evora-Portugal.

4. Aira, J.R.; Arriaga, F.; İñiguez-González, G.; Guaita, M.; Esteban, M. (2012) Analysis of the stress state of a halved and tabled traditional timber scarf joint with the finite element method, WCTE2012, World Conference on Timber Engineering, Auckland, New Zealand.

5. Burbano, S.; Burbano, E.; García, C. (1993) Física General, p. 950, Mira editores, XXXI edición, Zaragoza, España.

6. Glass, S.V.; Zelinka, S.L. (2010) Chapter 4: Moisture Relations and Physical Properties of Wood, Wood Handbook, Forest Products Laboratory, Madison, USA.

7. Bejo, L.; Lang, E.M.; Fodor, T. (2000) Friction coefficients of wood-based structural composites, Forest Products Journal, vol. 50, n 3 , pp. 39-43.

8. Serway, R.A.; Jewett, J.W. (2003) Física, $3^{\text {a }}$ edición, volumen 1, Thomson Editores, Madrid, España.

9. Kollmann, F. (1959) Tecnología de la madera y sus aplicaciones (Technologie des Loses und der Holzwerkstoffe), Instituto Forestal de Investigaciones y Experiencias y el Servicio de la Madera, Tomo 1, Ministerio de Agricultura, Madrid.

10. UNE-EN 1995-2:2010 Eurocódigo 5: Proyecto de estructuras de madera, Parte 2: Puentes.

11. ASTM G115-10 Standard Guide for Measuring and Reporting Friction Coefficients.

12. Crespo, J.; Regueira, R.; Soilán, A.; Díez, M.R.; Guaita, M. (2011) Desarrollo de metodología para la determinación de los coeficientes de fricción estático y dinámico de diferentes especies de madera, CIMAD $11,1^{\circ}$ Congreso Ibero-Latino Americano de la madera en la construcción, Coimbra, Portugal.

13. UNE-EN 408 Estructuras de madera, Madera aserrada y madera laminada encolada para uso estructural, Determinación de algunas propiedades físicas y mecánicas.

14. UNE-EN 13183-1 Contenido de humedad de una pieza de madera aserrada, Parte 1: Determinación por el método de secado en estufa. 